\title{
On Mertz and Ninnis Glaciers, East Antarctica
}

\author{
Gerd Wendler, Kristina Ahlnäs and Craig S. Lingle \\ Geophysical Institute, University of Alaska-Fairbanks, Fairbanks, Alaska 99775-7320, U.S.A.
}

\begin{abstract}
Two large glacier tongues, which extend substantially across the coastline of King George V Land in East Antarctica, have been studied by remote sensing (synthetic aperture radar, JERS-1). The tongue of Mertz Glacier is in a state of advance, while the Ninnis Glacier tongue is retreating. Some more specific points are:
\end{abstract}

The distinctive surface structure and the form of the glacier tongues indicates that they are floating.

While the tongue of Ninnis Glacier has lost about two-thirds of its area since 1913, the Mertz Glacier tongue has advanced substantially and has about doubled its areal extent over the same time period.

The annual movement of the tongue of Mertz Glacier was determined as about $1.2 \mathrm{~km}$. This is close to the value of the advance of the tip of the tongue since 1963 , which was determined as $0.9 \mathrm{~km}_{\text {year }}{ }^{-1}$.

\section{INTRODUCTION}

Mertz and Ninnis Glaciers are located in King George V Land, East Antarctica (Fig. 1). They are prominent features; the tongue of Mertz Glacier, presently the larger of the two, extends about $95 \mathrm{~km}$ into the ocean and has an average width of about $40 \mathrm{~km}$. This area of Antarctica was first explored by Sir Douglas Mawson during his heroic trip between 1911 and 1914. Mawson established his main camp at Cape Denison $\left(67.02^{\circ} \mathrm{S}, 142.68^{\circ} \mathrm{E}\right)$ in Commonwealth Bay. He and his team were surprised by the frequency and intensity of the katabatic winds which occur in this area. He gave a popular account in his book entitled The home of the blizzard (Mawson, 1915). The winds he experienced - mean annual speed of $19.6 \mathrm{~m} \mathrm{~s}^{-1}$ - are the strongest found anywhere on planet Earth close to sea level. His data were doubted but more recent observations with automatic stations, which record over satellite, have confirmed his findings (Stearns and Wendler, 1988).

Cape Denison is located close to the South Magnetic Pole and during the summer of 1912-13 two trips were

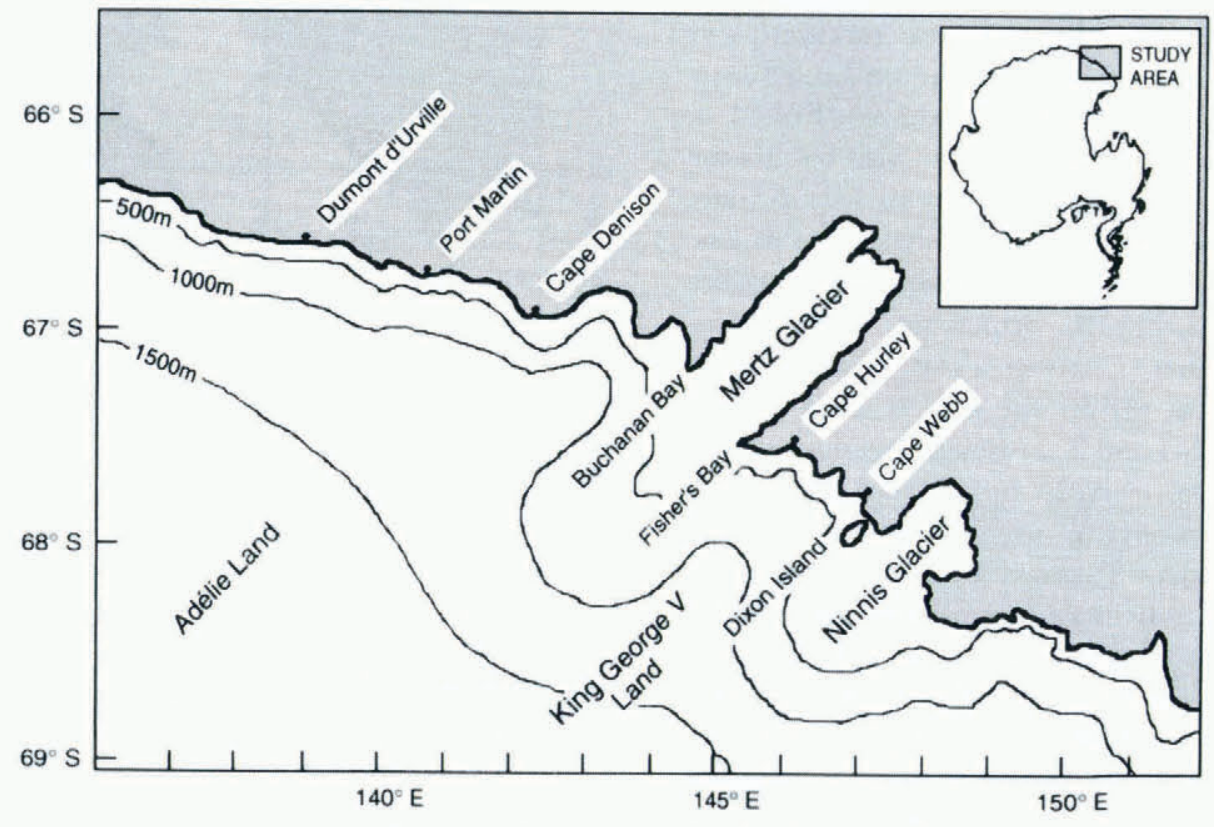

Fig. 1. Area map of King George V Land, East Antarctica. 
made towards the east. "The eastern coastal party" was under the leadership of C. T. Magidan. He and his two companions went by foot from Cape Denison pulling a heavy sled. They crossed the tongue of Mertz Glacier, which was difficult because of many crevasses. At the point of their crossing, which was relatively close to the coastline, they found a maximum elevation of $53 \mathrm{~m}$. This altitude is in good agreement with later measurements. The Australian map (SQ55-56) of this area, which was issued in 1971 and based on data from 1961-62, gave a maximum altitude of $49 \mathrm{~m}$ for the same general area. After crossing Mertz Glacier, they continued over the sea ice and crossed the tongue of Ninnis Glacier, where they determined a maximum elevation of $55 \mathrm{~m}$. Then they went on further to explore the coastal region east of Ninnis Glacier and eventually returned to Cape Denison. During their trip, they ran low on food and supplemented their supplies with penguins, which are plentiful in this area; they reported them to taste quite good.

The second party to the east, but at a more inland course, was "the far eastern party" under the leadership of Mawson. His two companions were Dr X. Mertz and Lieut. B. E. S. Ninnis. They crossed Mertz Glacier further inland and also reported very crevassed areas. After having crossed Ninnis Glacier, in an area about $150 \mathrm{~km}$ to the east, Ninnis and his dog team met their deaths in a large crevasse. This was even more tragic as his sled carried most of the food supply, which they were unable to retrieve. The trip home was a race against starvation; Mertz perished and Mawson himself barely survived. Mawson named these two glaciers after his fallen comrades.

\section{SATELLITE IMAGES}

The Alaska SAR Facility (ASF), which is operated under contract with NASA by the Geophysical Institute, University of Alaska-Fairbanks, is the only satellite synthetic aperture radar (SAR) receiving station in the United States. Data from the first and second European Remote Sensing Satellites (ERS-1 and ERS-2) and from the Japanese SAR satellite (JERS-1) are received and processed here. ERS-1 and 2 do not have on-board tape recorders, so SAR image data must be down-linked in real time to a receiving antenna that is "visible" to the satellites; that is, the satellites can acquire data only within the station masks of the receiving antennas. JERS-1 has an on-board tape recorder and can therefore acquire SAR data worldwide, which are then downlinked when the satellite is within a station mask. Our area of interest was not within the station mask of any ground station for ERS-1 and 2, although it is now within the station mask of the recently operational McMurdo antenna. (Also, a receiving station is now under construction at Hobart, Tasmania.) The SAR data employed in this study were acquired over East Antarctica by JERS-1; the data were subsequently down-linked and processed at ASF. The SAR on board JERS-1 is L-band $(1.27 \mathrm{GHz}$; wavelength $=0.235 \mathrm{~m}$ ) and has a swath width of $75 \mathrm{~km}$, a pixel spacing of $12.5 \mathrm{~m}$ in full resolution and a resolution of $30 \mathrm{~m}$. Lowresolution images have a pixel spacing of $100 \mathrm{~m}$ and a resolution of $240 \mathrm{~m}$. Unlike satellite imagery that is dependent on radiation of the visible or thermal IR range in which the surface can be seen only in the absence of clouds, radar images are unaffected by weather and darkness. SAR is therefore suitable for use in the polar regions during winter and in regions characterized by heavy cloud cover.

Velocity measurements were made using the ASF Interactive Image Analysis System (IIAS), which provides network access to the Arctic Data Visualization and Analysis Laboratory (ADVAL) and the Arctic Region Supercomputing Center (ARSC). Image-processing software on the IIAS includes the Land Analysis System (LAS), International Imaging System's (IIS) System 600, PCI and Khoros.

\section{LONG-TERM CHANGES}

Mawson's team was the first group to map the King George V Land coast, using measurements obtained between 1911 and 1914. The general outline of the tongues of Mertz and Ninnis Glaciers is included in his map (Mawson, 1915, p. 240). The Australians published maps on a scale of $1: 1000000$ of this area in 1971 (SR5556) and in 1974 (SQ55-56) (Australia 1971, 1974) based on observations carried out in 1961 and 1962. In 1993 , SAR imagery of this area was acquired by JERS-1. Figure 2 shows the outlines of the glacier tongues from all three sources. Table 1 shows the areas of the glacier tongues seaward of the coastline.

In the case of Mertz Glacier, the size of the tongue has increased substantially during this century. It has more than doubled its size, from about $3830 \mathrm{~km}^{2}$ in 1913 to about $8100 \mathrm{~km}^{2}$ at present. During the earlier part of this century, the glacier tongue mostly broadened but, since 1962, the glacier tongue has advanced about $26 \mathrm{~km}$ or about $0.9 \mathrm{~km}_{\text {year }}^{-1}$.

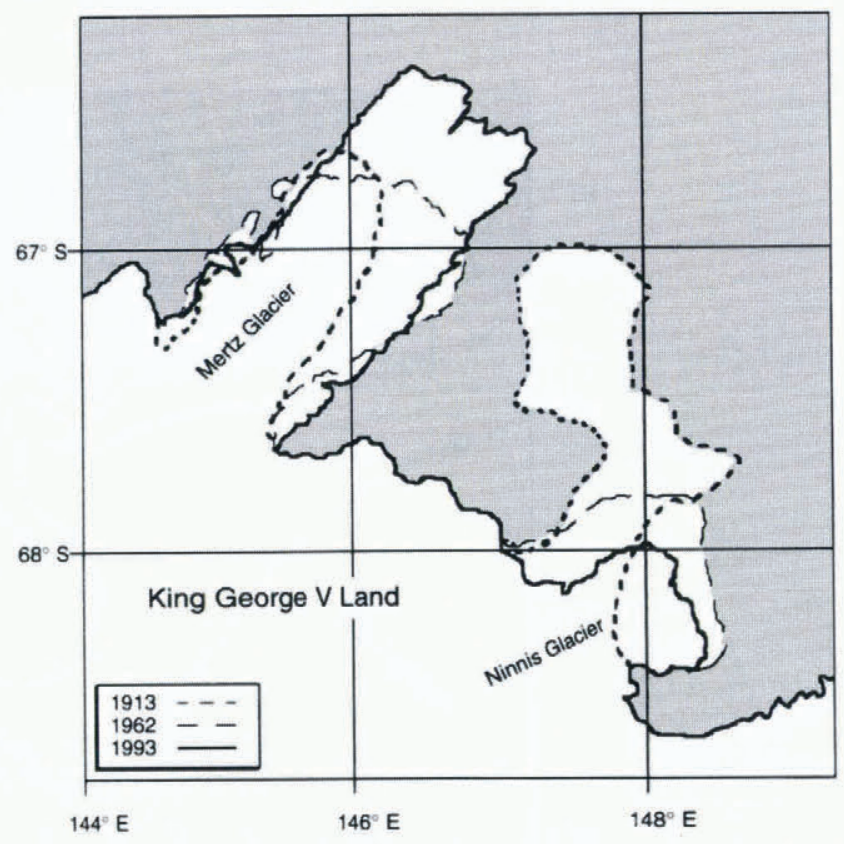

Fig. 2. The positions of the Mertz and Ninnis Glacier tongues in 1912-13, 1962 and 1993. 
Table 1. Areas of Mertz and Ninnis Glacier tongues in 1913, 1962 and 1993

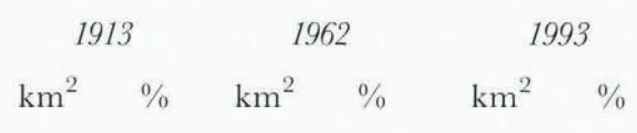

\begin{tabular}{ccccccc}
$\begin{array}{c}\text { Mertz } \\
\text { Glacier }\end{array}$ & 3830 & 100.0 & 5920 & 154.6 & 8100 & 211.3 \\
$\begin{array}{c}\text { Ninnis } \\
\quad \text { Glacier }\end{array}$ & 6060 & 100.0 & 3970 & 65.5 & 2150 & 35.4 \\
$\begin{array}{c}\text { Both } \\
\text { glaciers }\end{array}$ & 9890 & 100.0 & 9890 & 100.0 & 10250 & 103.6 \\
\hline
\end{tabular}

The behavior of the Mertz Glacier tongue is in sharp contrast to Ninnis Glacier. Here, we observe an extraordinary retreat since 1913 ; during the 80 year time period, the glacier tongue retreated $110 \mathrm{~km}$ and its area was reduced to about one-third of its original size. Most of the retreat was observed during the earlier part of this century. During 1913-62, it retreated about $90 \mathrm{~km}$; since 1962, retreat has continued.

Large decreases in size can result from episodic calving, if a glacier tongue is floating. Some depth measurements are available from the west side of the tongue of Mertz Glacier, where a water depth of about $350 \mathrm{~m}$ was found, while the water at the tip of the tongue was only about $250 \mathrm{~m}$ deep. A lesser depth in front of a glacier tongue is frequently found. Glaciers transport large quantities of sediment, which are predominantly deposited at the tip of the glacier tongue, in time making this area less deep than areas closer to the coast.

The water depth required for flotation at the seaward end of the Mertz Glacier tongue can be estimated using the equations of Lingle and others (1991; equations (14)(19)), which give density as a function of depth and mean density between a given depth and the surface based on density profiles measured in core holes on the Ross Ice Shelf. Their equation (19) gives the mean density of the ice shelf as a function of total thickness, for a firn-ice transition at a depth of $65 \mathrm{~m}$. If Mertz Glacier is "barely floating" in water $250 \mathrm{~m}$ deep at the calving front, a surface elevation there of $47 \mathrm{~m}$ would correspond to a total ice-shelf thickness of $297 \mathrm{~m}$. (The mean density of the ice shelf would then be $864.7 \mathrm{~kg} \mathrm{~m}^{-3}$. A density of $1028 \mathrm{~kg} \mathrm{~m}^{-3}$ is assumed for sea water.) If the surface clevation at the calving front is as high as $50 \mathrm{~m}$, however, then a water depth of $270 \mathrm{~m}$ would be required for flotation, corresponding to a total ice-shelf thickness of $320 \mathrm{~m}$. (The mean density of the ice shelf would then be $868.2 \mathrm{~kg} \mathrm{~m}^{-3}$.) A height of $53 \mathrm{~m}$ was the maximum elevation measured on the glacier tongue but the mean height is around $40 \mathrm{~m}$. This indicates that Mertz Glacier is not grounded at its seaward end.

Alaskan glaciers grounded in deep fjords characteristically advance by maintaining their termini in stable positions in shallow water, on the crest of a moraine where the water depth is of the order of 10-100 $\mathrm{m}$ (Meier and Post, 1987). The terminus advances by abrading debris from the up-glacier side of the moraine and dumping it over the crest on to the proglacial side in the style of a bulldozer. This process can gradually advance the terminus out over the length of a relatively deep fjord on a time-scale of the order of 1000 years (Meier and Post, 1987 ; i.e. at a mean advance rate of roughly $10-100 \mathrm{~m}_{\text {year }}^{-1}$.

In the case of the Mertz Glacier tongue, however, Figure 2 shows that the terminus advanced about $26 \mathrm{~km}$ between 1964 and 1993; i.e. at a mean rate of about 900 mear $^{-1}$. Comparison of SAR images acquired during 1993 and 1994 (Fig. 3) yielded an advance rate of $1200 \mathrm{~m}$ year $^{-1}$, which suggests that the average advance rate during 196493 was less because of modest, episodic iceberg calving. The relatively high rate of advance during both time periods, combined with an absence of morphology and crevasse patterns characteristic of compressive flow at the calving point, implies that the Mertz Glacier tongue is floating for its entire length and that the advance mechanism is more likely to be analogous to the Erebus Glacier tongue, Antarctica (Holdsworth, 1974), than to Alaskan fjord glaciers. That is, the floating glacier tongue is advancing at a rate equal to the velocity of the ice stream where it crosses the grounding line, plus an additional increment of velocity due to longitudinal strain rates induced by hydrostatic imbalance at the ice front, less the calving rate.

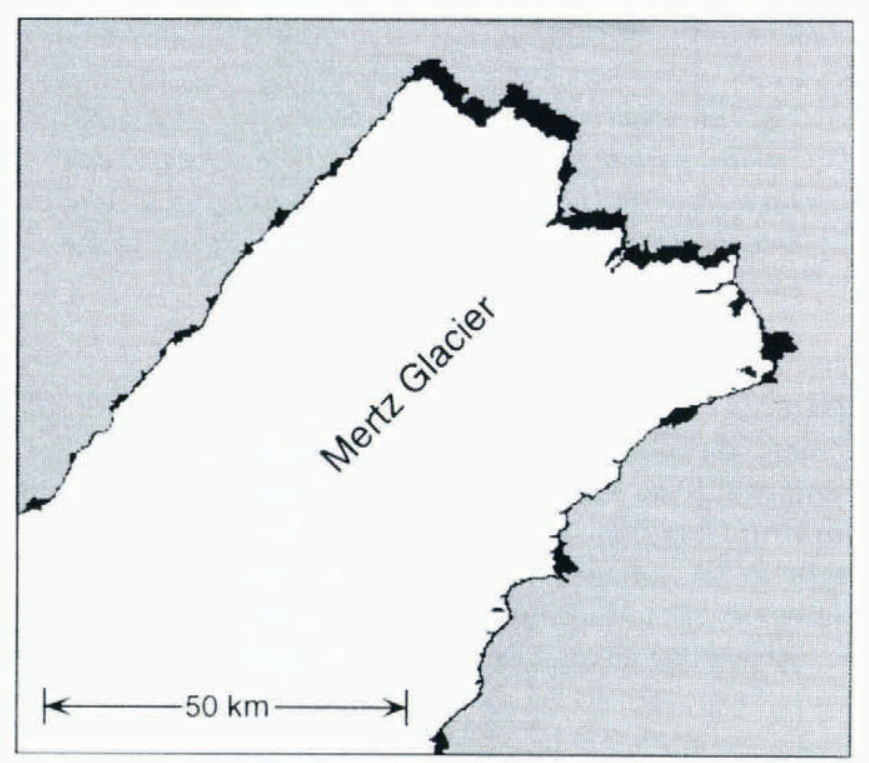

Fig. 3. A sketch of the advance of the Mertz Glacier tongue for the 19 month period June 1993-December 1994. This sketch was obtained by subtracting the two SAR images from each other.

In Figure 4, a drawing is shown indicating the hypothesized relationship between the crevasse pattern on the Mertz Glacier tongue and stress, associated with the transition from marginal shear to longitudinal stress and orthogonal normal stresses on the tongue. The indicated velocity profile (dashed vectors) on the grounded ice stream was hypothesized, not measured, and is shown only to indicate the probable restraining influence of shear along the margins. The crevasse pattern on the floating ice tongue is hypothesized due to the longitudinal stress regime and is in good agreement with the crevasse 


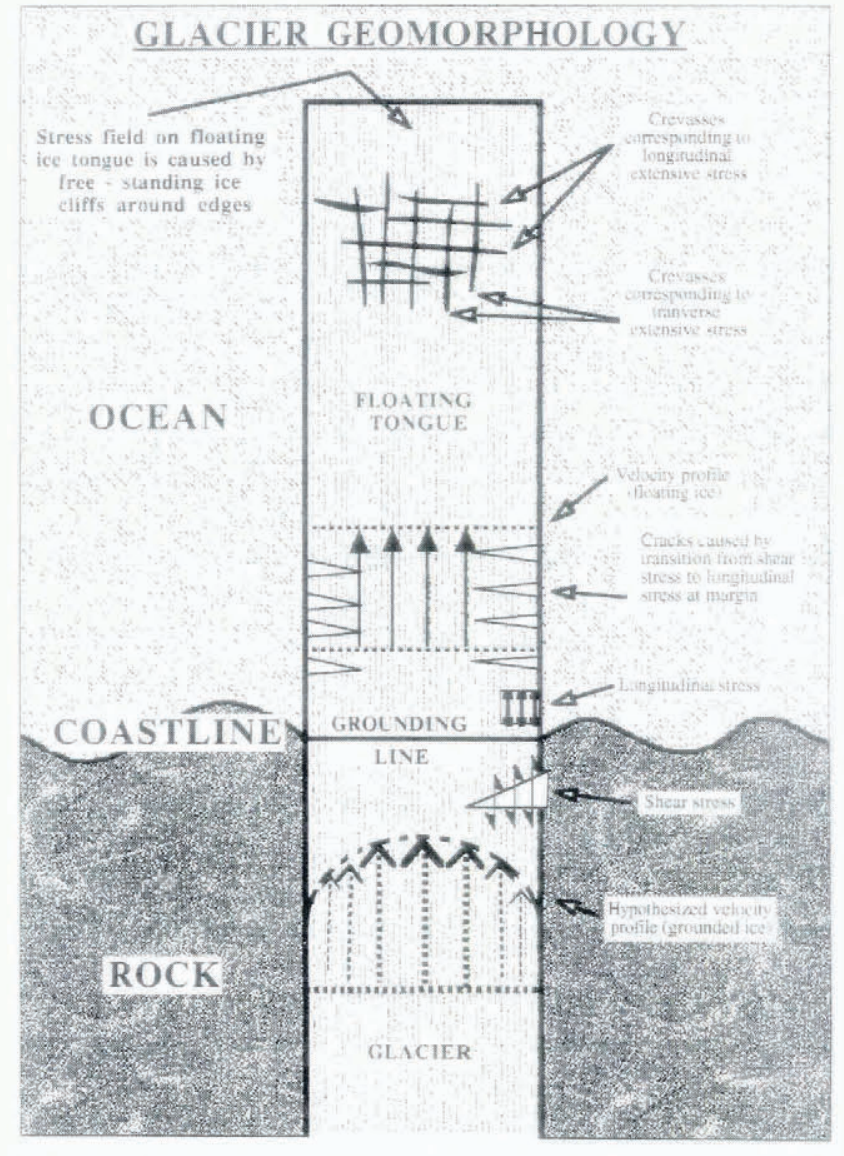

Fig. 4. Drawing indicating hypothesized relationship between crevasse pattern on the Mertz Glacier tongue and stress, associated with the transition from marginal shear to longitudinal stress and orthogonal normal stresses on the glacier tongue.

pattern observed on the glacier tongue (see also Fig. 8). When the glacier is viewed in visible light (Fig. 5), remarkably no surface features are detected. This results from the fact that the visible part of the spectrum reflects light at the surface, while microwave radiation can partially penetrate the snow to a certain extent.

Regarding advance versus retreat and considering the

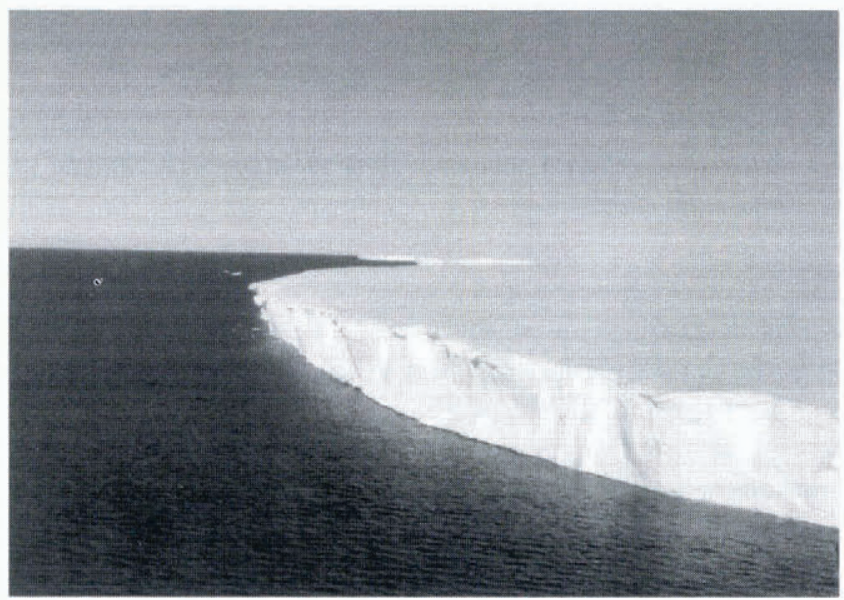

Fig. 5. Aerial photograph of the floating Mertz Glacier tongue taken in December 1994 showing the height of the terminus as approximately $40 \mathrm{~m}$. sum of the area of the two glaciers, hardly any losses or gains have been realized since 1913; the observed 3.6\% increase in areal extent is within the accuracy of the measurements. The behavior of these two glaciers, lying next to each other in the same climatic zone, again shows how difficult it is to relate the behavior of advances or retreats of floating glacier tongues to climatic change (e.g. Sturm and others, 1991). In this case, opponents or proponents of global warming will each find one glacier to support their ideas. Generally speaking, there has been some temperature increase observed for this area over the last three decades (Wendler and Pritchard, 1991; Periard and Pettré, 1993). This, of course, does not necessarily mean that glaciers should retreat, as with increased temperature increased snow accumulation might be expected. However, we were unable to verify this because, due to the high wind speeds, precipitation measurements have not been carried out at Dumon d'Urville, the only long-term station in the general area.

\section{SHORT-TERM CHANGES}

We have obtained one SAR (JERS-1) image of Ninnis Glacier (Fig. 6), which shows this glacier in a state of break-up and dramatic retreat. There are two images of Mertz Glacier; one image was taken close to mid-winter (30 May 1993), while the second was obtained close to mid-summer (23 December 1994), being about 19 months apart in time. Hence, short-term changes could only be analyzed for the latter glacier. When comparing the two images (Fig. 7), the most amazing fact is the similarity between them, and a closer examination is needed to see the differences. The L-band SAR on board JERS-1 probably "sees through" the dry winter snow. The sea ice is more pronounced in the winter image, an observation to be expected. While the high ice concentration is expected in winter, there is a large amount of sea ice for the mid-summer scene. However, the summer of 1994-95 was one of the most severe in the region. The French had major problems in resupplying their main station, Dumont d'Urville, and by this time of the year they had been unable to reach their station by supply ship. We were in the area a few days after this image was obtained and, even with the powerful USCG Cutter Polar Star we stayed about 30 miles offshore and flew in by helicopter on 28 December 1994, visiting Cape Webb, located on an ice-free outcrop between Mertz and Ninnis Glaciers.

In the winter scene, less sea ice can be seen on the west side of the glacier tongue; "streaks" of newly formed ice can be observed and, from the direction of these streaks, a southeasterly wind direction can be deduced. This wind direction was confirmed from our coastal automatic weather stations.

Other differences to be observed in the SAR images are:

There is a different number of small icebergs in front of the glacier tongue. These icebergs break off periodically from the glacier. Especially, when the water is ice-free, they can be a spectacular sight.

One of the two large floating icebergs to the east of the Mertz Glacier tongue, originating from Ninnis 


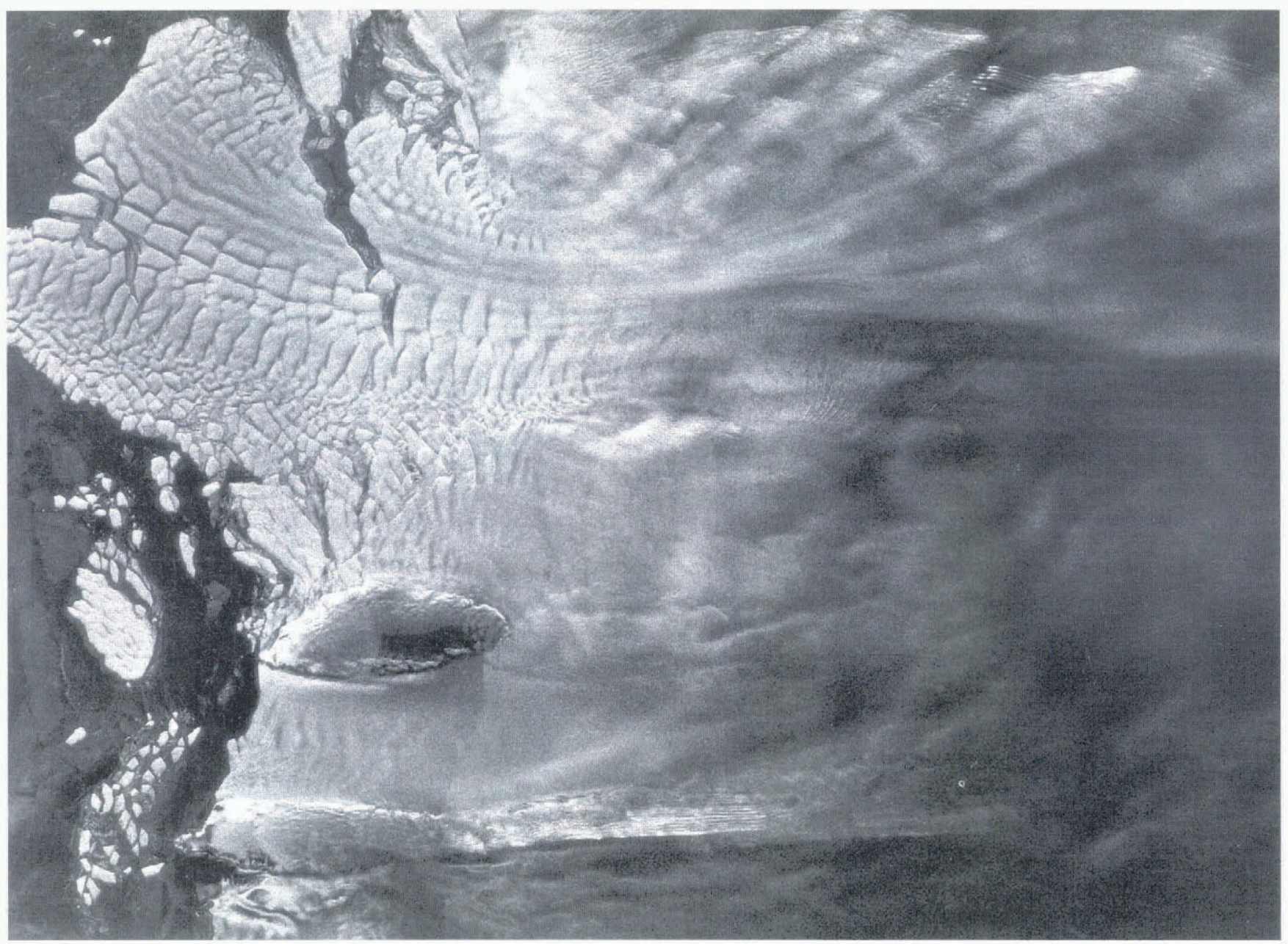

Fig. 6. SAR (JERS-1) image of Ninnis Glacier, 1993.

Glacier, has disappeared in the second image.

The large floating iceberg to the east of the glacier tongue is somewhat rotated. It has a size of $45 \mathrm{~km}$ by about $18 \mathrm{~km}$ and it also originated from Ninnis Glacier.

Naturally, we were also interested in the movement of the glacier. For this, some "fixed" points had to be established. We found these at Buchanan Bay to the west of Mertz Glacier and at Cape Hurley at Fisher's Bay to the east of the glacier. Flicking back and forth on the computer screen between the two images, the movement of the glacier could be seen, as there is sufficient structure to see specific points. We determined the speed at three cross-sections of the glacier: line A close to the coastline, line $\mathrm{B}$ about $50 \mathrm{~km}$ from the coastline and line $\mathrm{C}$ towards the tip of the ice tongue (Fig. 8). The speed was quite uniform and no statistically valid differences could be detected for the three lines. The absence of a velocity decrease toward the tip, where the ice is thinner, is again an indication that the entire glacier tongue is floating. In all cases, the movement for the 19 month time period varied between 1500 and $2000 \mathrm{~m}$. A mean value of motion of $1010 \mathrm{~m}$ year ${ }^{-1}$ was determined. This is in fair agreement with the advance of the glacier tongue, for which we had found a mean value of $900 \mathrm{~m}$ annually. It should be pointed out that measuring the displacement is not as simple as might be expected. This is not caused by the resolution; the pixel size is $12.5 \mathrm{~m}$, which results in a nominal resolution of about $30 \mathrm{~m}$ but rather by identifying clearly the same point in both images.

Subtraction of the digital versions of the two images yielded a "difference image" from which changes could be seen, especially in front of the glacier tongue (Fig. 3). If no calving had occurred, these values represent the advance of the glacier tongue. The advance is fairly uniform along the whole front of the glacier, which might be taken as an indication that calving played only a minor role during the 19 month period. In any case, values deduced in this way represent a minimum in movement. Again, values around $1 \mathrm{~km}$ year $^{-1}$ were found.

Perhaps the most striking aspect of the surface is the orthogonal pattern of intersecting crevasses (Fig. 8). This structure is not found farther inland on the glacier. Inland, parallel crevasses perpendicular to the direction of movement are dominant. This is the structure to be expected and found on other glaciers (Paterson, 1994). The cells on Mertz Glacier, which are quite visible on the glacier tongue, have a width of $1-2 \mathrm{~km}$.

Knowing the glacier thickness close to the coastline, the glacier speed and the width of the glacier tongue, the total export of ice from Mertz Glacier can be estimated as $12.7 \mathrm{~km}^{3}$ water year ${ }^{-1}$. The total area of Mertz Glacier is about $60000 \mathrm{~km}^{2}$. This estimate is based on altitude elevations obtained in digital format from the Scott Polar Research Institute. Hence, on average, Mertz Glacier exports an annual $212 \mathrm{~mm}$ w.e. accumulation of snow and ice. The only manned station at Dumont d'Urville does not measure precipitation, as the times with strong winds 


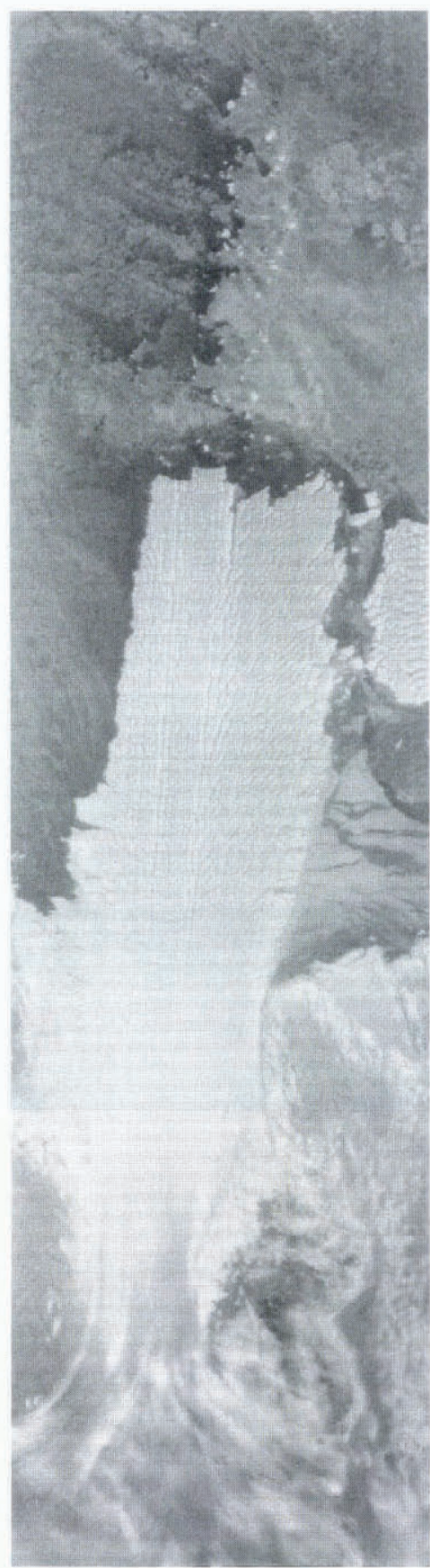

30 MAY 93

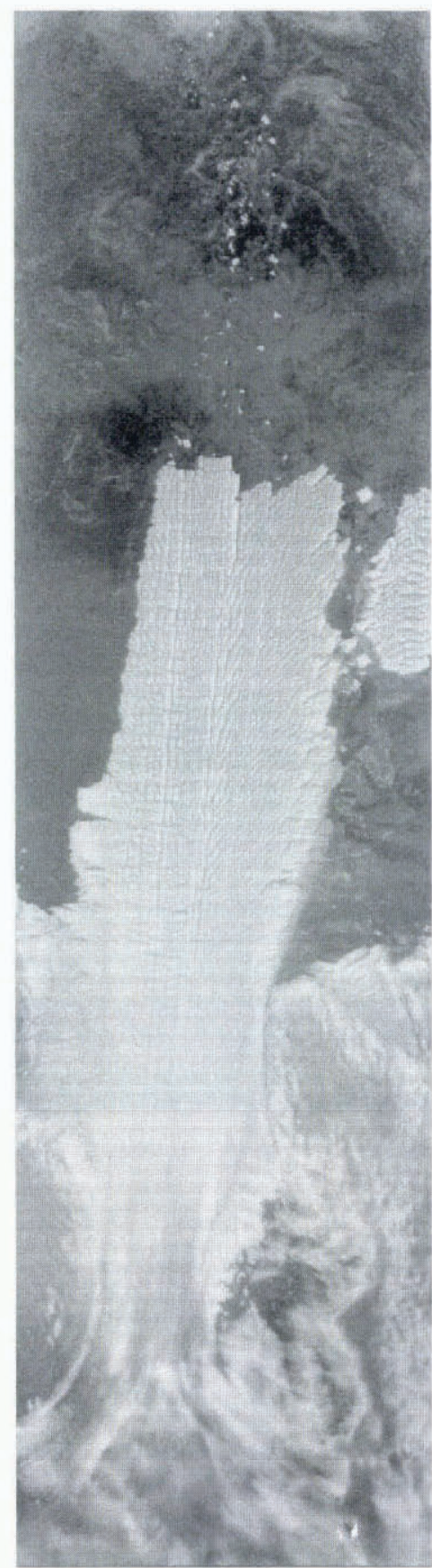

23 DEC 94

Fig. 7. SAR (JERS-1) images of Mertz Glacier taken about 19 months apart from each other. True north is $32^{\circ}$ to the right.

are too frequent to obtain meaningful values. Furthermore, it is sometimes impossible to distinguish between "falling" and "blowing" snow.

Giovinetto (1964) gave estimates of precipitation over the Antarctic ice sheet. A value of $250 \mathrm{~mm}$ year $^{-1}$ w.e. might be deduced from his maps as the mean for the Mertz Glacier basin. Hence, the glacier apparently exports about $85 \%$ of the snow and ice accumulated over the catchment area. The rest may be accounted for by snow blowing over the coastline into the ocean (Loewe, 1972; Giovinetto and others, 1992), if these glaciers are in equilibrium.

It should be pointed out that this is a very rough estimate, as two of the three values on which this number is based are approximations:

(a) The size of the glacier basin is difficult to determine in the upper areas, where the slope angles are very small.

(b) The precipitation values for the basin are only estimates; there is a fairly steep gradient in the precipitation in the coastal area.

Nevertheless, this export of $15 \%$ of the precipitation due to blowing snow appears to be a reasonable value for this area in which very high wind speeds are observed (Wendler and others, 1994). 


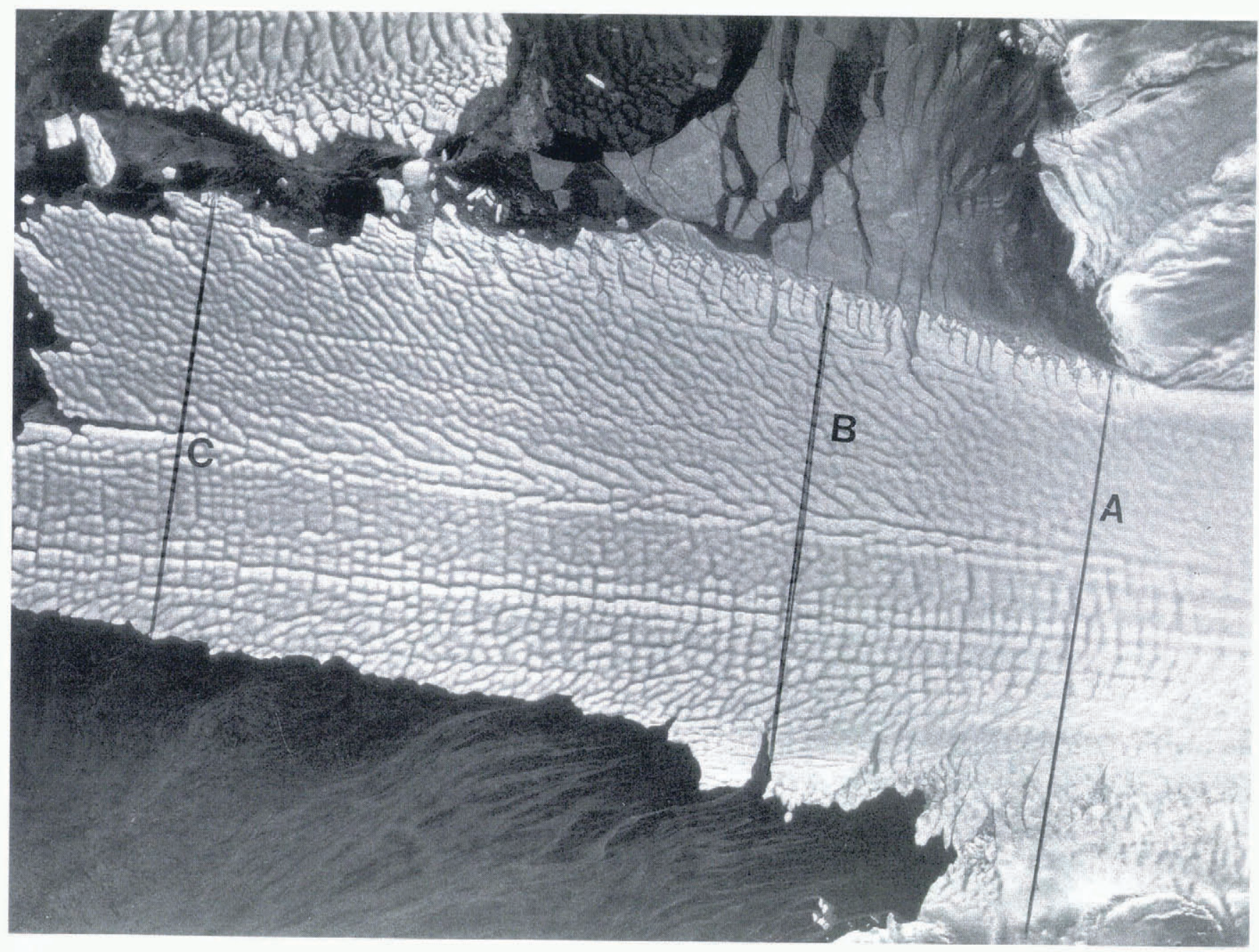

Fig. 8. An enlargement of the tongue of Merlz Glacier. Note the particular cellular structure on the glacier surface. True north is $32^{\circ}$ to the right. A, B and $C$ are the three cross-sections along which the movement of the glacier was determined.

\section{ACKNOWLEDGEMENTS}

We should like to thank the following: the personnel of the Alaska SAR Facility who were very helpful and B. Moore who did the computer work. Financial support was obtained from the United States National Science Foundation, OPP, grant 94-13879.

\section{REFERENCES}

Australia. 1971. Map of the Mertz Glacier. 1:1,000,000. Canberra Department of Minerals and Energy. Division of National Mapping. (SR55-56.

Australia. 1974. Map of King George Land. 1:1,000,000. Canberra Department of Minerals and Energy. Division of National Mapping. (SQ55-56.)

Giovinetto, M. B. 1964. The drainage systems of Antarctica: accumulation. In Mellor, M., ed. Antarctic snow and ice studies. Washington, DC, American Geophysical Union, 127-155. (Antarctic Research Series 2.)

Giovinetto, M. B., D. H. Bromwich and G. Wendler. 1992. Atmospheric net transport of water vapor and latent heat across $70^{\circ}$ S. J. Geophys. Res., 97 D1), 917-930.
Holdsworth, G. 1974. Erebus Glacier tongue, McMurdo Sound, Antarctica. 7. Glaciol., 13 (67), 27-35.

Lingle, C. S., D. H. Schilling, J. L. Fastook, W. S. B. Paterson and T. J. Brown. 1991. A flow band model of the Ross Ice Shelf, Antarctica; response to $\mathrm{CO}_{2}$-induced climatic warming. 7. Geophys. Res., 96 (B4), 6849-6871.

Loewe, F. 1972. The land of storms. Weather, 27, 110-121.

Mawson, D. 1915. The home of the blizzard; being the story of the Australasian Antarctic Expedition, 1911-1914. London, Heinemann.

Meier, M. F. and A. Post. 1987. Fast tidewater glaciers. J. Geophys. Res., 92 B9), 9051-9058

Paterson, W.S. B. 1994. The physics of glaciers. Third edition. Oxford, etc., Elsevier.

Periard, C. and P. Pettré. 1993. Some aspects of the climatology of Dumont d'Urville, Adélie Land, Antarctica. Int. J. Climatol., 13, 313-327.

Stearns, C. and G. Wendler. 1988. Research results from Antarctic automatic weather stations. Rev. Geophys., 26 (1), 45-61.

Sturm, M., D. K. Hall, C. S. Benson and W. O. Field. 1991. Nonclimatic control of glacier-terminus fluctuations in the Wrangell and Chugach Mountains, Alaska, U.S.A. J. Glaciol., 37 (127), 348 356.

Wendler, G. and D. Pritchard. 1991. Temperature increase observed in Adélie Land, East Antarctica? Antarct. J. U.S., 26 5), 281-284.

Wendler, G., J. C. André, P. Pettré, J. Gosink and T. Parish. 1994 Katabatic winds in Adélie Land. In Bromwich, D. H. and C. R. Stearns, eds. Antarctic meteorology and climatology: studies based on automatic weather stations. Washington, DC, American Geophysical Union, 23 45. Antarctic Research Series 61. 